AgnieszKa GromKowsKa-MelosiK

ORCID 0000-0002-6303-0384

Uniwersytet im. Adama Mickiewicza

$w$ Poznaniu

\title{
WYSOKIE OBCASY \\ I KONSTRUKCJE TOŻSAMOŚCI KOBIET. \\ DYNAMIKA ASYMETRII PŁCIOWEJ, SEKSUALNOŚCI I EMANCYPACJI
}

\begin{abstract}
AвSTRAct. Gromkowska-Melosik Agnieszka, Wysokie obcasy i konstrukcje tożsamości kobiet. Dynamika asymetrii płciowej, seksualności i emancypacji [High Heels and Constructions of Women's Identity. Dynamic of Gender Asymmetry, Sexuality and Emancipation]. Studia Edukacyjne nr 52, 2019, Poznań 2019, pp. 61-86. Adam Mickiewicz University Press. ISSN 1233-6688. DOI: 10.14746/se.2019.52.5
\end{abstract}

The article is devoted to the role of high heels in the construction of feminine identity. The various contexts of the main problem are analysed. The first one refers to the use of high heels as a confirmation of men's domination over the feminine body, and identity. The second one is connected with sexual connotations of high heels. And the third one with the paradoxical use of the high heels as a source of women's emancipation. The main thesis of the article is based on the assumption that every, even smallest feminine (or masculine) thing is involved into contradictory values and practical consequences.

Key words: high heels, identity, emancipation, sexuality, fashion, androcentrism

Dajcie dziewczynie właściwe buty, a podbije świat

Marylin Monroe

Niezależnie od przyjętego punktu widzenia, ubrania są nieodłącznym elementem codziennego życia człowieka; nie tylko chronią ciało, lecz mają zdolność jego modyfikacji, zakrywając jego poszczególne części lub eksponując inne. Ze względu na ich „intymną relację" z ciałem i tożsamością, można mówić o ",języku” i „psychologii” ubioru1. Stanowią one także istotny komponent relacji społecznych, również i w kontekście władzy/upodmiotowie-

${ }^{1}$ E. Wilson, Adorned in Dreams. Fashion and Modernity, New York 2003, s. VIII. 
nia. Niezależnie przy tym od epoki historycznej, dążenie do atrakcyjnego wyglądu jest wpisane w konstrukcję tożsamości kobiet w znacznie większym stopniu niż mężczyzn. Nie ulega też wątpliwości, że wygląd kobiety stanowi zawsze podstawowy, wyjściowy wyznacznik identyfikacji. Jest on ekspresją oczekiwań społecznych, które z jednej strony mogą być postrzegane w kontekście narzucanych kobietom androcentrycznych standardów i norm, z drugiej - w kontekście świadomej ich akceptacji przez kobiety. Z kolei, historyczne zmiany ideałów pięknego ciała są wyrazem złożonych interakcji ewolucji społecznej roli kobiet i dominującej ideologii kobiecości oraz wiedzy naukowej i medycznej², jak również konsekwencją zmian w zakresie społecznych ról kobiet i ich relacji z mężczyznami. Zawsze jednak kobiety oceniane są $\mathrm{w}$ dużej mierze przez pryzmat ich zdolności do adaptacji wobec akceptowanych powszechnie przekonań dotyczących ciała, jego fizyczności i seksualności. Istotnego znaczenia nabiera tu kategoria "władzy”. Idealne ciało stanowi bowiem - jak twierdzi wielu krytyków - środek sprawowania społecznej kontroli nad umysłami i życiem kobiet. Susan Bordo uważa, że analiza dziejów tej jednej choćby praktyki społecznej, jaką jest moda, prowadzi do wniosku, iż społeczna manipulacja ciałem kobiecym jest podstawową strategią w potwierdzaniu asymetrycznych stosunków między kobietami i mężczyznami, zawsze na niekorzyść tych pierwszych ${ }^{3}$. Z kolei David Kunzle ujmuje to w nieco innym aspekcie, dostrzegając dwojaki charakter władzy wpisanej w modę: płciowy i klasowy. Zauważa on, iż

moda jest kulturowo dominującym wyrażaniem sposobu ubierania się, z zasady, klasy dominującej. Może jednak wyrażać, w sposoby, które nie w pełni rozumiemy, nieznaczne niuanse zmieniających się relacji między płciami, jak również między segmentami dominujących, rywalizujących czy przemieszczających się w górę drabiny społecznej klas ${ }^{4}$.

Jednocześnie przy tym panująca ideologia cielesności (i seksualności) wikła zwykle kobiety, przynajmniej (choć nie tylko) z wyższych klas społecznych, w neurotyczne sprzeczności, które sprawiają, iż żyją one w nieustannym niepokoju, dotyczącym swojego ciała. Ten niepokój stanowi formę „regulowania” ich tożsamości, a często redukowania aspiracji życiowych do walki o „adekwatne” ciało5.

${ }^{2}$ P. Vertinsky, Body Shapes: The Role of the Medical Establishment in Informing Female Exercise and Physical Education in Nineteenth-Century North America, London 1987, s. 257.

${ }^{3}$ S. Bordo, Unbearable Weight. Feminism, Western Culture and the Body, Berkeley - Los Angeles - London 1995, s. 143.

${ }^{4}$ D. Kunzle, Fashion and Fetishism. Corsets, tight-lacing and other forms of Body Sculpture, London 2006, s. 1.

${ }^{5}$ Na ten temat piszą m.in. Z. Melosik, Tożsamość, ciało i władza w kulturze instant, Kraków 2010; A. Gromkowska, Kobiecość w kulturze globalnej. Rekonstrukcje i reprezentacje, Poznań 2002; 
Z drugiej jednak strony, z perspektywy poglądów postfeministycznych i poststrukturalistycznych, trzeba zauważyć, że dostosowywanie się do wymogów mody i kanonów piękna, może być postrzegane jako wolny wybór kobiety, który sprawia jej przyjemność. Podnoszony przez tradycyjny feminizm problem przemocy symbolicznej, przejawiający się w zjawisku narzucania kobietom dominujących standardów piękna jest kwestionowany przez eksponowaną przez poststrukturalizm zasadę „oddolnego nadawania znaczeń" ${ }^{6}$, kiedy to opresjonowani wychodzą poza schematy męskiej represji (znakomicie jest to widoczne w całym nurcie pop-feminizmu ${ }^{7}$ ). Znakomicie ujmuje to Emily Maguire, kiedy pisze:

nikt nie powinien osądzać innych kobiet za ich wybory, czy sprawiać aby czuły się przez nie winne czy też żądać odrzucania działań z powodu ich związku z „kultem kobiecości"8.

Ponadto, szeroko rozumiana emancypacja kobiet przyniosła rekonstrukcje „potocznej świadomości”, której integralną częścią jest współcześnie przekonanie, że kobieta ma władzę w sferze kreowania własnej tożsamości i reprezentacji własnego ciała, jak również własnej biografii. Trudno zaprzeczyć, że takie symbole „zniewolenia” jak makijaż, atrakcyjny, a nawet seksualny strój, wysokie obcasy (nazywane kiedyś przez feministki radykalne „butami gwałtu”9 - uniemożliwiają ucieczkę przed napastnikiem; stukot szpilek jest pierwszym sygnałem zbliżającej się ofiary ${ }^{10}$ ) łączą się w świadomości wielu o ile nie większości kobiet - z przyjemnością, satysfakcją i zwiększeniem poczucia własnej wartości. Także przedstawicielki niektórych odłamów feminizmu uważają, że wszystkie te atrybuty (w tym

A. Gromkowska-Melosik, Kobieta epoki wiktoriańskiej. Tożsamość, ciało, medykalizacja, Kraków 2013.

${ }^{6}$ J. Fiske, Understanding Popular Culture, London - New York 1991, s. 19-21; por. też J. Chambers, Cities without Maps, [w:] Mapping the Futures. Local Cultures, Global Change, red. J. Bird, London 1993, s. 191-193.

7 Postfeminizm opiera się na założeniu, iż dawne ideały feministyczne zostały zrealizowane, nadszedł więc czas, w którym kobieta może skoncentrować swoją uwagę na własnej samorealizacji i wyborze stylu życia. Zwolennicy postfeminizmu zakładają, że istnieje coraz więcej kobiet, które nie widzą ograniczeń w dziedzinie tego, kim mogą być lub co mogą (z)robić w życiu. Postfeminizm proponuje ideał kobiety wyzwolonej, świadomej swojej seksualności i niezależnej. Jednakże - jak twierdzą krytycy - taki ideał tworzy jedynie mit postępu i redukuje problemy społeczno-polityczne do osobistych (tym bardziej że postfeministki w praktyce orientują się głównie na konsumpcję i ciało. W tym kontekście pisze się ironicznie, że główne hasło postfeminizmu brzmi: „jesteśmy wolne - chodźmy na zakupy”). Szerzej na ten temat: A. Gromkowska, Kobiecość w kulturze globalnej, s. 83-85.

${ }^{8}$ E. Maguire, Princessess and Pornstars: Sex, Power, Identity, Melobourne 2008, s. 43.

9 S. Cline, D. Spender, Reflecting Men: At Twice Their Natural Size, London 1987, s. 67.

${ }^{10}$ V.S. Maass, The Cinderella Test: Would You Really Want the Shoe to Fit? Subtle Ways Women Are Seduced and Socialized into Servitide and Stereotypes, Oxford 2009, s. 16. 
buty na wysokich obcasach) dodają kobietom nie tylko atrakcyjności, ale sprawiają, że uzyskują one społeczną widzialność i zyskują pewien zakres władzy; także i nad spojrzeniem mężczyzn, a niekiedy ich umysłami i seksualnością. Uważa się więc, że stroje, makijaż i biżuteria (oraz inne dodatki kobiecości/ kobiecej zmysłowości) mogą być traktowane przez kobiety jako element (przyjemnej) zabawy własnym wizerunkiem, a także dostarczać poczucia upodmiotowienia i przez to być elementem emancypacji. Tyrania mody wraz z jej dyscyplinującymi praktykami nie stanowi w kontekście zarówno postfeminizmu, jak i potocznej świadomości „problemu ideologicznego"; jest kwestią „wyboru” dokonanego przez kobietę, która sama decyduje o swoim wizerunku, a także i biografii. Jak ujmują to Avelie Stuart i Ngaire Donaghue,

neoliberalny dyskurs pozwala kobietom przypisać ich działania własnym pragnieniom i zdolności do podejmowania wyborów, a także ignorowania przymusowości (tych działań) $)^{11}$.

W ten sposób postrzegają one siebie jako osoby działające w sposób autonomiczny,

samostanowiące i nie będące pasywnymi ofiarami opresyjnych ideologii, które usuwają potrzebę krytyki ${ }^{12}$.

Powrócę jednak w tym miejscu do tezy, której istotą jest przekonanie, że moda stanowi formę podporządkowania kobiet. W takim podejściu powierzchowność kobiety, jej „zewnętrzność”, uroda, wygląd i ubiór rozpatrywane są w kontekście - powtórzę - męskiej dominacji. Można przywołać tutaj choćby poglądy Thorsteina Veblena, który pisał, iż kobieta z „,klasy próżniaczej” była przeznaczona dla teatru społeczeństwa - odpowiednika arystokratycznego dworu z minionej ery ${ }^{13}$. Jej ciało (a w konsekwencji i umysłowość) było dyscyplinowane poprzez obowiązującą modę oraz etykietę dotyczącą właściwej ekspresji obowiązujących ideałów kobiecości, odnoszących się zarówno do „zewnętrzności” kobiety, jak i - w konsekwencji - jej tożsamości oraz możliwych do zaakceptowania pełnionych przez nią ról społecznych. Trudno nie zgodzić się z twierdzeniem, iż

z perspektywy historycznej, wzornictwo ubrań i obuwia dla mężczyzn potwierdzało ich władzę i miejsce w sferze publicznej, zapewniając mobilność i bezpieczeństwo.

${ }_{11}$ A. Stuart, N. Donaghue, Choosing to conform: The discursive complexities of choice in relation to feminine beauty practices, Feminism and Psychology, 2011, 22(1), s. 118.

12 Tamże.

${ }^{13}$ G. Duby, M. Perrot, A History of Women in the West, t. IV, Cambridge - Massachusetts London 1995, s. 321. 
Dla kontrastu [ubiory - uzup. AG-M] buty kobiece stawiały modę ponad funkcjonalnością ${ }^{14}$.

Przy czym, to kobiety zawsze były bliższe niż mężczyźni modzie, miały większą świadomość jej znaczenia w codziennym życiu i od zawsze miały wyrafinowaną

wiedzę na temat społecznego znaczenia ubioru i etykiety towarzyszącej nawet najbardziej prostym częściom garderoby ${ }^{15}$

- choć oczywiście rzadko umieszczały ją w kontekście relacji władzy i androcentrycznego panowania.

Niniejszy tekst zostanie poświęcony jednej tylko części ubioru kobiecego - butom, w ich specyficznej, uważanej za kobiecą postaci - butów na wysokim obcasie.

Wybór nie jest tu przypadkowy, ponieważ stanowią one niezwykle obszerne źródło wiedzy, między innymi, socjologicznej, antropologicznej, historycznej, medycznej, a ich

wygląd może wyrażać abstrakcyjne historyczne koncepcje (...), a także ucieleśniać ideały i estetyczne wybory epoki.

Trudno nie zgodzić się z Georgio Riello, kiedy pisze on, iż

buty mogą powiedzieć nam wiele o jednostce, ale zawierają też treści, które mogą być odczytane w kontekście społecznym ${ }^{16}$.

Ich bogate zdobienie lub jego brak, delikatne bądź solidne podbicie, kształt i kolor zawsze wskazywały na kondycję finansową właściciela i jego status społeczny. Bez wątpienia, symbolika butów może być też odczytywana w kontekście moralności lub jej braku, seksualności, a także przynależności do płci. Nic więc dziwnego, że Rossie dzieli buty na cztery kategorie „seksualne, bezpłciowe, neutralne i biseksualne". Za najbardziej kobiece i seksowne uważa wysokie i bardzo smukłe obcasy, które sprawiają, że

stopa wygląda na mniejszą, łuk i podbicie są bardziej zaokrąglone, noga jest dłuższa i kształtniejsza a biodra i pośladki rozkołysane ${ }^{17}$.

\footnotetext{
${ }^{14}$ A. Matthews David, Fashion Victims: The Dangers of Dress Past and Present, London 2015, s. 12.

${ }^{15}$ Ch. Bayles Kortsch, Dress Culture in Late Victorian Women's Fiction. Literacy, Textiles, and Activism, Burlington 2009, s. 55.

${ }^{16}$ G. Riello, P. McNeil, Footprints of History, History Today, 2000, 57, 3, s. 30.

17 S. Jeffreys, Beauty and Misogyny: harmful Cultural Practices in the West, London 2015, s. 128.
} 
Zgodnie z tytułem książki Susan Reynolds Change your Shoes, Change Your Life. Strut Your Way to Fabulous NewYou butom na wysokim obcasie przypisuje się magiczną moc... potrafią przeistoczyć „zwykłą dziewczynę w gwiazdę roc$\mathrm{ka}^{18 "}$, "księżniczkę czy boginię seksu" ${ }^{19}$. A ich mit przeobrażenia życia zwykłego Kopciuszka ${ }^{20} \mathrm{w}$ księżniczkę jest zakorzeniony głęboko w kulturze światowej za sprawą braci Grimm... i oczywiście w szerszym kontekście - w relacji do całej ideologii amerykańskiego marzenia.

Buty na wysokich obcasach są określane jako

„narzędzie władzy”, działające na wyobraźnię, a nawet posiadający zdolność do transformacji symbol kobiecości, uwodzenia, fantazji, ale także jako „instrument tortur”21.

Emocje, jakie wywołują wysokie obcasy są niezwykle gorące i skrajnie przeciwstawne. Od uwielbienia do nienawiści. (To właśnie buty na wysokich obcasach, a nie jak się powszechnie uważa staniki, obok gorsetów i pasów do pończoch - jako symbole opresyjnej ideologii kobiecości zostały spalone w „koszu wolności" (freedom trash can) w 1968 roku na znak protestu przeciwko seksizmowi i rasizmowi towarzyszącym konkursowi piękności w Atlantic City ${ }^{22}$ ). Stanowią przy tym atrybut tak pożądany, iż noszenie ich podczas wielogodzinnych zakupów, jazdy na rowerze, w ciąży, a także na plaży, czy w trakcie prowadzenia samochodu (w połowie lat 90 . XX w. policja uznała buty na sześciocalowej platformie za niebezpieczne podczas prowadzenia samochodu na równi z używaniem telefonu komórkowego i byciem pod wpływem alkoholu ${ }^{23}$ ) jest absolutnym fenomenem kulturowym. Warto też dodać, że Hotel Hilton Osaka wprowadził obniżki cen dla klientek w zależności od wysokości ich obcasów - minimalna to $5 \mathrm{~cm}$, za $15 \mathrm{~cm}$ szpilki można uzyskać 40\% zniżki na rachunek w restauracji lub barze ${ }^{24}$. Uważa się je za obuwie uniwersalne

wysokie obcasy nie są przeznaczone wyłącznie NA WIECZÓR. Znakomicie pasują do spodni, dżinsów, dżinsowych spódniczek, mini i piżamy ${ }^{25}$.

Bez wątpienia są one jednym z najbardziej wyraźnych symboli kobiecości. Pisząc o płci kulturowej, Sylviane Agaciński zauważa, że

\footnotetext{
${ }^{18}$ L. Tanenbaum, Bad Shoes and Women Who Love Them, New York 2010, s. 6.

19 Tamże, s. 10.

${ }^{20}$ Szerzej o butach Kopciuszka: A. Gromkowska-Melosik, Kopciuszek. Zagubiony szklany pantofelek i metamorfozy kobiecości, Studia Edukacyjne, 2017, 46.

${ }_{21}^{21}$ M-A. Parmentier, High heels, Consumption Markets \& Culture, 2016, 19, 6, s. 511.

${ }^{22}$ H. Hinds, J. Stacey, Imaging Feminism, Imagine Femininity: The Bra-Burner, Diana and the Woman Who Kills, Feminist Media Studies, 2001, 1, 2, s. 157.

23 A. Matthews David, Fashion Victims, s. 12.

${ }^{24}$ The Reason Why This Japanese Bar Gives Discounts to Women Will Blow Your Mind, 16 June 2017, https://www.alux.com/hilton-osaka-hotel-japan/

${ }^{25}$ C. Morton, How to Wear High Heels. The Girls Guide to Everything, Paris 2006, s. 23.
} 
tożsamość płciową trzeba nieustannie odgrywać, trzeba w niej „przesadzać”, aby stać się tym, kim się „jest”. Kobieta, która wkłada buty na obcasie i maluje sobie usta, jest doskonale świadoma tego, że przebiera się za kobietę ${ }^{26}$.

Buty na obcasie są przy tym jednym z najbardziej rozpoznawanych symboli kobiecości, iż pragnący zamanifestować swoją kobiecość transwestyci nigdy z nich nie rezygnują; bieg w szpilkach jest elementem parady równości ${ }^{27}$.

Nic więc dziwnego, że fraza „wysokie obcasy” jest użyta w setkach tytułów książek jako metafora kobiecości (od symbolu narzucania nierealnych często standardów kobietom po receptę na pełnienie tradycyjnie męskich ról w kobiecy sposób, np. w zarządzaniu, polityce, czy prawie). Przykładem mogą być następujące tytuły: Natalie Aiman Wall Street in High Heels (2011), autobiografia Loni Anderson My Life in High Heels, Zaidie Crowe Carnegie Warriors in High Heels (2007), Deborah J. McLaughlin Running in High Heels. How to Lead with Influence, Impact and Ingenuity (2014), Christina Conners From High Heels to Bunny Slippers: Surviving the Transition from Career to Home (2006), poradnik Crystal Brown-Tatum Saltwater Taffy and Red High Heels. My Journey Through Brest Cancer (2008), czy Winsome Campbell-Green High Heels in Tech (2013).

David Kunzle przyrównuje wysokie obcasy do gorsetu, nazywając je

syjamskim rodzeństwem, wzmacnianymi przez te same historyczne, psychologiczne, i być może komplementarne fizjologiczne okoliczności.

Uważa przy tym, że są one narzędziem kształtowania tego fragmentu ciała, jakim jest stopa,

tradycyjna kompresja palców stóp czyni ją spiczastą w kształcie, podczas gdy natura stworzyła ją szeroką i prostokątną i to jest bardzo znaczące (...), ale bardziej znaczący jest sposób, w jaki wysokie obcasy radyklanie modyfikują wachlarz działań stopy, i poprzez to postawę i krok noszącej je osoby (...) zmieniając postawę ciała i jego ruchy, jako kinetyczna rzeźba ${ }^{28}$.

Wysokie obcasy nie zawsze jednak były atrybutem kobiet. Ich geneza może wydawać się zaskakująca, bowiem, zdaniem niektórych historyków kultury, używali ich staroegipscy rzeźnicy, aby ochronić swoje stopy od krwi

${ }^{26}$ S. Agaciński, Polityka ptci, Warszawa 2000, s. 18-19.

${ }^{27}$ Rainbow flags and High heels, South Korea holds debut drag parade, 28.05.2018, http:/ / www.richmond-news.com/news/asia-pacific-news/rainbow-flags-and-high-heels-s-korea-holds-debut-drag-parade-1.23315577; M. Payton, Men's High Heels Race During Spanish Gay Pride is Simply Fabulous, 5. July 2015, https:/ / metro.co.uk/2015/07/05/mens-high-heel-race-during-spanish-gay-pride-is-simply-fabulous-5281244/

${ }^{28}$ D. Kunzle, Fashion and Fetishizm, s. 5. 
zwierzą ${ }^{29}$. Inni badacze są przekonani, że stanowiły one atrybut jeźdźców na Bliskim Wschodzie. Przykładem może być uwieczniony na wazie perskiej z IX wieku wizerunek mężczyzny ubranego w buty na wysokich obcasach, które umożliwiają mu trzymanie nóg w strzemionach. Można więc stwierdzić, iż były one niezwykle użyteczne dla jeźdźców (także dla kowbojów). Europejczycy „zapożyczyli” je dopiero w XVI wieku jako symbol statusu; najpierw nosili je mężczyźni z najwyższych warstw społecznych, następnie kobiety i dzieci ${ }^{30}$. Buty na wysokich obcasach stały się popularne w warstwie arystokratycznej w Europie na początku XVII wieku i zostały upowszechnione przez Persów. Uznawano, iż ich noszenie nadaje mężczyznom bardziej dostojny i męski wygląd. Ich rozprzestrzenienie się do warstw niższych spowodowało, iż "arystokratyczny" obcas stał się wyższy ${ }^{31}$. Szereg autorów zajmujących się historią obuwia za szczególnie istotny uważa portret Ludwika XIV, który wysokimi obcasami rekompensował sobie niski wzrost. Obcasy oraz podeszwy butów przeznaczonych dla klas wyższych były wówczas koloru czerwonego, który symbolizował bogactwo (choćby ze względu na kosztowność barwnika), ale również miał nawiązywać do metaforyki militarnej. W latach 70. XVII wieku król wydał edykt zezwalający na noszenie wysokich czerwonych obcasów wyłącznie dworzanom, lecz buty na wysokich obcasach stały się tak pożądane, iż kopiowano je w sposób nielegalny ${ }^{32}$. Jako symbol statusu i najwyższej cnoty były także nakładane zmarłym świętym (Hilary Davidson pisze o Świętym Antonim i Świętym Piotrze, których obuto po śmierci, aby podkreślić ich zasługi dla Kościoła ${ }^{33}$ ).

Jednym z najstarszych rodzajów butów na wysokich obcasach są koturny (tzw. pianelle) - buty na bardzo grubej podeszwie, zwykle korkowej lub drewnianej. Niektórzy autorzy przypisują im wartość użytkową ponaddekoracyjną; twierdzą oni, że były one popularne w średniowiecznej Europie ze względu na stan ulic - pozwalały suchą stopą przejść przez miasto ${ }^{34}$. Jednak zdaniem Riello i McNeil, ta koncepcja jest mało wiarygodna. Ich zdaniem, buty te miały być emblematem statusu - nosząca je kobieta nie mogła się poruszać

${ }^{29}$ L. O'Keeffe, Shoes: A Celebrations of Pumps, Sandals, Slippers, and More, New York 1996, s. 73 .

${ }^{30}$ M. Keane, B. Monte, Sex, Power, and High Heels: An Interview with Shoe Curator Elizabeth Semmelhack, Collectors Weekly, 2010, June, 18 th. https:/ / www.collectorsweekly.com/articles/ sex-power-and-high-heels-an-interview-with-shoe-curator-elizabeth-semmelhack/

${ }_{31}$ W. Kremer, Why did men stop wearing High Heels, The BBC, January 25, 2013, https:// www.bbc.com/news/magazine-21151350.

32 Tamże.

33 H. Davidson, Holding the Sole. Shoes, Emotion and Supernatural, [w:] Feeling Things: objects and emotions, Through History, red. S. Downes, S. Hollowey, S. Randles, Oxford 2018, s. 86.

${ }_{34}$ G. Riello, P. McNeil, Footprints of History, s. 31; M. Barnish, H. May Morgan, J. Barnish, The 2016 High Heels: Health effects and psychosexual benefits study: systematic review of reviews and additional primary studies, BMC Public Health, 2018, 18, s. 37. 
swobodnie, co powodowało, iż stawała się dekoracyjnym obiektem niezdolnym do pracy fizycznej ${ }^{35}$ i taki pogląd znakomicie wpisuje się w koncepcję postrzegania ich jako instrumentu podporządkowania kobiet mężczyznom. W podobnym tonie wypowiada się John Evelyn, pisząc o weneckich kobietach z klas wyższych noszących buty na wysokich obcasach, które

wymyślono po to, aby zatrzymać je $\mathrm{w}$ domu, bardzo trudno się w nich przemieszcza (...) stąd muszą one opierać się na służących $(\ldots)^{36}$.

Riello i McNeil przyrównują natomiast noszenie pianelle do zwyczaju krępowania stóp w starożytnych Chinach, przez co sugerują ich seksualne konotacje $^{37}$. Z kolei, Maria Giuseppina Muzzarelli wskazuje na inny kontekst ich użycia - w Japonii oraz Indiach miały one charakter rytualny podczas ceremonii ślubnej lub innych obrzędów ${ }^{38}$.

Warto zwrócić uwagę na uwarunkowania noszenia butów na koturnach w XVII wieku. Georgio Riello i Peter McNeil podają tu przykład Henri Missona, który w Memoirs and observation pisał o konieczności ich noszenia przez kobiety na brudnych chodnikach Londynu. Nie miały one jednak konotacji seksualnych, lecz jak zauważają autorzy, stanowiły symbol pozycji społecznej ${ }^{39}$. Do podobnych konkluzji dochodzi Turner-Wilcox, który pisze, iż noszenie butów na wysokich obcasach było zarezerwowane dla klas wyższych, a w niektórych krajach zależne także od stanu cywilnego. Podaje on przykład zamężnych hiszpańskich arystokratek ${ }^{40}$, a także zamożnych ludzi w starożytnych Indiach ${ }^{41}$. Mamy tutaj więc do czynienia nie tyle z wykorzystywaniem butów na wysokich obcasach do reprodukowania różnic płciowych, co klasowych nierówności społecznych. Linda O'Keeffe podaje, iż po raz pierwszy butów na wysokim obcasie jako wyrazu próżności użyła Katarzyna Medycejska w 1533 roku, przywożąc je z Florencji na ceremonię zaślubin z Księciem Orleańskim i rozpoczynając w ten sposób modę na ten typ obuwia we Francji $^{42}$. W Wielkiej Brytanii moda na wysokie obcasy rozpowszechniła się w wieku XVIII. Wtedy były one tak wysokie, że kobiety musiały podpierać się laseczkami ${ }^{43}$. Książe Vaulanc przyrównywał kobiety do lalek, pisząc

${ }^{35}$ G. Riello, P. McNeil, Footprints of History, s. 32.

36 A. Swallow, The history of shoes, Baillieres Clinical Reumathology, August 1987, 1, 2, s. $420-421$.

37 G. Riello, P. McNeil, Footprints of History, s. 33.

38 Tamże, s. 32.

39 Tamże, s. 33.

40 R. Turner Wilcox, The Mode in Footwear: A Historical Survey with 53 Plates, New York 2008, s. 111.

41 Tamże, s. 40.

${ }^{42}$ L. O'Keeffe, Shoes: A Celebrations of Pumps, s. 30.

${ }^{43}$ G. Riello, P. McNeil, Footprints of History, s. 34. 
w swoich Memoirs o tych, które poruszając się na niebotycznych obcasach, z łatwością mogły przewrócić się ${ }^{44}$.

Ambiwalencję wokół tego przedmiotu pożądania może odzwierciedlać fakt, iż w 1770 roku w brytyjskim parlamencie pojawiła propozycja ustawy, w której zakazywano kobietom noszenia wysokich obcasów jako narzędzi uwodzenia i zdrady:

wszystkie kobiety, niezależnie od ich pozycji, wieku czy zawodu, dziewice, mężatki czy wdowy, (...) noszące buty na wysokich obcasach (...) będą podlegać karze (...), a ich małżeństwo po wyroku skazującym zostanie unieważnione ${ }^{45}$.

Istnieją także inne przekazy o uznawaniu butów na wysokich obcasach za symbol grzechu; warto też dodać, iż istnieją wzmianki, w których uznawano je za buty niemoralne ${ }^{46}$, a nawet za znak rozpoznawczy prostytutek ${ }^{47}$, co potwierdzać mogą zapisy świadczące o tym, iż w XV wieku w wielu włoskich miastach zakazano noszenia ich ze względów religijnych ${ }^{48}$. Z kolei, wystawiona w 1865 roku w Paryżu Olympia, namalowana przez Moneta, wywołała skandal, ponieważ nie była alegorią piękna - buty na obcasie dodane do nagiego ciała nadają obrazowi charakter pornograficzny - vojerystyczna przyjemność patrzenia na nagie ciało osiągnięta jest tu przez jego połączenie ze sferą publiczną ${ }^{49}$ (warto dodać, że we współczesnych przekazach o treściach pornograficznych buty na bardzo wysokich obcasach są symbolem kobiecej dominacji).

Zakaz ich noszenia wydał także - choć z zupełnie innych względów niż moralność - Napoleon, który w ten sposób chciał zamanifestować pierwsze z rewolucyjnych haseł: równość. Odtąd każda warstwa społeczna miała nosić buty na płaskiej podeszwie, jako znak braterstwa i braku podziałów klasowych. Kiedy w 1793 roku Maria Antonina wstępowała na szafot, miała na sobie buty na wysokich obcasach, pokazując opór wobec tej idei ${ }^{50}$. Jej pantofelek na sześciocentymetrowym słupku stanowi część wystawy w Muzeum w Rouen ${ }^{51}$. Komentująca to wydarzenie M. Linder, podkreśla, że ironią jest,

44 Tamże.

${ }^{45}$ Za: S. Benstock, S. Fernill, Footnotes on shoes, London 2001, s. 10.

${ }^{46}$ G. Riello, P. McNeil, Footprints of History, s. 32.

47 Piszą o tym, m.in.: M.G. Muzzarelli, Sumptoumous Shoes Making and wearing in Medieval Italy, [w:] Shoes. A History from sandals to sneakers, red. G. Riello, P.McNeil, Oxford - New York 2006, s. 65; V. Steele, Shoes and the Erotic Imagination, [w:] Shoes. A History from sandals to sneakers, s. 265.

${ }^{48}$ G. Riello, P. McNeil, Footprints of History, s. 33.

${ }^{49}$ E. Semmelhack, A Delicate Balance: Women, Power and High Heels, [w:] Shoes. A History from sandals to sneakers, s. 230.

${ }^{50}$ The Mystery of High Heeled Shoes: the Past and the Present, s. 4, https:/ / www.shs.edu. tw/works/essay/2012/04/2012040309301379.pdf

${ }^{51}$ M. Toussaint-Sammat, Historia stroju, przekł. K. Szeżyńska-Maćkowiak, Warszawa 1997, s. 394 . 
iż kojarzone z opresją i bezczynnością burżuazji wysokie obcasy (wówczas noszone przez mężczyzn) zostały zniesione przez rewolucję francuską po to, by wrócić w połowie XIX wieku jako symbol arystokratycznej kobiecości ${ }^{52}$. Thoerstein Veblen pisze o tym w sposób następujący:

wysokie obcasy, spódnica, niepraktyczny czepek, gorset i generalne ignorowanie komfortu osoby je noszącej jest oczywistą cechą ubioru (...) kobiety zależnej od mężczyzny (...) stanowiącej jego majątek ${ }^{53}$.

Zdaniem Veblena, wysokie obcasy świadczą o stronieniu od pracy fizycznej, pewnego rodzaju ułomności fizycznej, udomowieniu, które ma być emblematem bogactwa i prestiżu jej mężczyzny.

Ten sposób rozumowania obecny był w myśleniu jednego z weneckich senatorów, który w 1655 roku postulował zwiększenie wysokości ośmiocalowego obcasa,

aby żony i córki nie mogły łatwo opuszczać domu i nie miały wolności w zakresie poruszania się po mieście (...), co doprowadzi rodzinę do ruiny ${ }^{54}$.

Znakomitą ilustracją tej tezy jest artykuł z XIX wieku, którego autor opisuje buty na wysokich obcasach pochodzące z XVIII wieku. Wskazuje na ekstremalną wysokość obcasa, która wymusza niemal „wertykalne ułożenie stopy" 55 . Podkreśla również, że w czasach mu współczesnych wysokie obcasy nie zostały zdetronizowane pomimo krytyki lekarzy. Powołuje się na wykład Frederica Trevesa, chirurga, który wypowiada się o niedorzeczności noszenia wysokich obcasów w następujący sposób:

trudno sobie wyobrazić coś bardziej niezgrabnego niż chód połowy naszych amerykańskich kobiet. Przemieszczające się w błotnistych kałużach na wysokich obcasach z wąskimi tunikami wokół kolan są postrzegane z równą trwogą, jak w zimie, gdy ich ręce są uwięzione w mufkach, stają się bezradne jak lalki w oknie wystawowym i równie łatwo mogą stracić równowagę $e^{56}$.

W jeszcze ostrzejszym tonie utrzymany jest artykuł w z 1908 roku:

Pierwszym i natychmiastowym rezultatem noszenia wysokich obcasów jest ogólny dyskomfort fizyczny. Powoduje to szybkie zmęczenie, większe rozdrażnienie i po-

${ }^{52}$ M. Linder, Smart Women, Stupid Shoes, and Cynical Employers: e Unlawfulness and Adverse Healt Consequences of Sexually Discriminatory Workplace Footwear Requirements for Female Employees, Journal of Corporation Law, 1997, 2, 2, s. 329.

53 T. Veblen, The Thoery of the Leisure Class, London 2000, s. 127.

54 A. Vianello, Courtly Lady or Courtesman? The Venetian Chopine in the Ressaince, [w:] Shoes. A History, from sandals to sneakers, s. 92.

55 Art in Dress, The Art Amateur, 1882, 7, 4, s. 84-85.

56 Tamże. 
jawiają się symptomy nerwowego załamania. (...) Normalne oddychanie jest niemożliwe i w rezultacie cierpi każdy organ ciała. Prędzej czy później te zmiany przekształcają żywotne dziewczę w osobę pozbawioną energii, różowe policzki bledną, wyprostowana sylwetka garbi się, zdrowa, pełna życia osoba staje się w połowie lub w całości niepełnosprawna ${ }^{57}$.

Co ciekawe, w tym właśnie okresie - pod koniec XIX wieku - następuje erotyzacja szpilek - stają się one obowiązkowym dodatkiem na zdjęciach przedstawiających akty kobiet $^{58}$.

Współcześnie moda zmienia się z sezonu na sezon, a kobieta ma niespotykaną w przeszłości możliwość w dziedzinie wyboru własnego stylu ubierania się. Style współistnieją i wzajemnie mieszają. Cytaty z lat 60. XX wieku są pokazywane w nowej odsłonie, a wiktoriańskie koronki łączone z wojskowymi kurtkami... na festiwalu filmowym Cannes obok powłóczystych sukni w stylu empire możemy zobaczyć krótkie spódniczki i duże dekolty nawiązujące swoją stylistyką do plaży. Kolory i wzory są dowolne. W zależności od sezonu, czerwony, zielony lub żółty odgrywają rolę zarezerwowaną w przeszłości do klasycznej czerni. Jedno pozostaje niezmienne - wysokie obcasy, które z sezonu na sezon wydają się być wyższe i stanowią warunek nieodzowny każdej stylizacji. Okazuje się też, że są częścią etykiety, począwszy od festiwalu filmowego w Cannes (gdzie kobiety w obuwiu na płaskim obcasie zostały wykluczone z przejścia po czerwonym dywanie, jako nie spełniające zasad $\left.d r e s s \operatorname{cod} u^{59}\right)$, skończywszy na pracy recepcjonistki $\mathrm{w}$ firmie rachunkowej (zwolnionej z pracy za odmowę noszenia wysokich obcasów, które były koniecznym elementem jej służbowego wizerunku ${ }^{60}$ ). Obowiązek ich noszenia, regulowany przez przepisy prawne poszczególnych firm, jak również przez oczekiwania kulturowe wobec kobiet jest przedmiotem debaty, nie tylko w potocznym dyskursie, ale także w rozważaniach o charakterze naukowym. Warto zrekonstruować fragmenty dyskursu wokół wysokich obcasów jako symbolu „nowoczesnej, heteronormatywnej kobiecej seksualności" ${ }^{11}$. Bez wątpienia rację ma Sheila Jeffreys, kiedy pisze, że

${ }^{57}$ Ladies Home Journal, January 1908, podaję za: N.E. Rexford, Women's Shoes in America, 1795-1930, Kent 2000, s. 65.

${ }^{58}$ W. Kremer, Why did men stop wearing High Heels, The BBC, 2013, January 25, https:/ / www.bbc.com/news/magazine-21151350.

59 H. Freeman, Can't Do Heels? Don't Do Cannes, "Guardian", 2015, 20 May, https://www. theguardian.com/commentisfree/2015/may/20/heels-cannes-r"ed-carpet-flat-shoes

${ }^{60}$ N. Khomami, Receptionis "sent home from PwC for not wearing high heels", https:/ / www. theguardian.com/uk-news/2016/may/11/receptionist-sent-home-pwc-not-wearing-high-heels-pwc-nicola-thorp

${ }^{61}$ M. Barnish, H. May Morgan, J. Barnish, The 2016 High Heels, s. 37. 
wysoki obcas nie ma żadnego sensu praktycznego. Nie ma wartości funkcjonalnej ani utylitarnej. Jest nienaturalny. Sprawia, że stanie czy chodzenie jest niebezpieczne i męczące. Jest zagrożeniem bezpieczeństwa. Jest oskarżany o powodowanie chorób podologicznych i innych ${ }^{62}$.

Wiele feministycznie zorientowanych badaczy uważa, iż noszące je kobiety "stają się niepełnosprawne” i „ograniczone w swojej fizycznej wolności”63. „Noszenie wysokich obcasów powoduje ból, niepełnosprawność, i często trwałą deformację" możemy przeczytać w Beauty and misogyny: harmful cultural practices in the West, gdzie Jeffreys opisuje je jako "szkodliwą praktykę kulturową społeczeństw zachodnich" ${ }^{64}$. Autorka ta porównuje tyranię wysokich obcasów ze zwyczajem krępowania stóp w Chinach ${ }^{65}$ (tezę tę znajdujemy również w rozważaniach Barbary Bergmann) ${ }^{66}$. Uważa ona, że wysokie obcasy są symbolem patriarchalnej kultury, w której mężczyzna wyznacza standardy piękna kobiecego ciała, a kobieta podporządkowuje się im, aby zaspokoić jego pragnienia, kosztem swojego komfortu i zdrowia. Ujmuje to w sposób następujący:

kobiety można rozpoznać natychmiast po tym jak z trudem spacerują na palcach swoich stóp w miejscach publicznych. W ten sposób wysokie obcasy pozwalają kobietom hołubić męskość - podziwiając rolę niezachwianego stojącego na dwóch stopach mężczyzny, która jest jasnym dowodem kruchości i wrażliwości kobiecej (...) pozwala to mężczyznom na pomaganie kobietom przy wejściu i zejściu z krawężników, przy wysiadaniu z samochodu, ponieważ są one podatne na upadek i skręcenie kostki ${ }^{67}$.

Sandra Lee Bartky pisze o tym następująco:

chód kobiety jest ostrożny. Jeśli podporządkowała się dodatkowemu ograniczeniu, jakim są buty na wysokich obcasach, jej ciało jest pochylone do przodu i pozbawione równowagi. Walka o to, by spacerować w takich warunkach skraca jej krok jeszcze bardziej ${ }^{68}$.

Z kolei Lilijana Burcar zauważa, że wysokie obcasy są narzędziem kapitalistycznej patriarchii i jako takie mają na celu

${ }^{62}$ Rossi, 1989, s. 19 podaję za: S. Jeffreys, Beauty and Misogyny, s. 128.

${ }_{63}$ M. Barnish, H. May Morgan, J. Barnish, The 2016 High Heels, s. 37.

${ }^{64}$ S. Jeffreys, Beauty and Misogyny, s. 119.

${ }^{65}$ Podobną tezę, choć w kontekście seksualności kobiety, stawiają Georgio Riello, Peter McNeil, Footprints of History, s. 32.

${ }^{66}$ E. Boris, Feminist Currents, Frontiers, A Journal of Women Studies, 2010, 31, 1, s. 166-167.

${ }^{67}$ S. Jeffreys, Beauty and Misogyny, s. 120.

68 S. Lee Bartky, Femininity and Domination: Studies in the Phenomenology of Opression, New York 1990, s. 68. 
rekonfigurację kobiet i ich ciał, jako symbolicznie i dosłownie, niewielkich i niestabilnych, wrażliwych i bezradnych, i jako seksualnie uprzedmiotowionych i utowarowionych ${ }^{69}$.

Natomiast, Claudia Wobovnik w swoim krytycznym artykule pisze, że wysokie obcasy

dając poczucie wdzięku, elegancji i luksusu - poczucie wysokiej samooceny, równocześnie są symbolem opresji, władzy, dominacji (...) stając się wizualnymi kulturowymi znacznikami kobiecości ${ }^{70}$.

Ambiwalencja wokół symboliki wysokich obcasów i znaczeń nadawanych im przez różne kobiety jest jednak tak znacząca, że - aby powrócić do dyskusji na temat roli butów na wysokich obcasach jako instrumentu dominacji/emancypacji - Eileen Boris w swoich refleksjach na temat reżimu mody kobiecej dzieli kobiety na dwie grupy, ze względu na ich podejście do wysokich obcasów: te, które czują się ofiarą mody i te, które po prostu bawią się tą modą. Niezależnie jednak zauważa ona, że wysokie obcasy dla wielu kobiet, mimo ich feministycznej świadomości, są w czymś w rodzaju... amuletu; dodają nie tylko wzrostu, ale i pewności, a kobiety potrafiące poruszać się w nich szybko „agresywnie zawłaszczają przestrzeń i czas"71.

Szczególną odmianą butów na wysokim obcasie są stiletto (szpilki) - obcasy ekstremalnie wąskie i wysokie tak, iż przypominają szpilkę bądź sztylet, przez co ich noszenie bardzo wysmukla nogę i całą sylwetkę.

Po co operacje plastyczne czy siłownia? - pyta Camilla Morton w książce Jak spacerować na wysokich obcasach? szpilki są najbardziej efektywnym natychmiastowym środkiem wyszczuplającym ${ }^{72}$ i dodaje: im węższy obcas, tym wyższe podbicie stopy tym wyższy status i bardziej prestiżowa sytuacja (...) to najważniejszy symbol damy ${ }^{73}$.

Szpilki zostały wynalezione w latach 50. XX wieku jako przeciwieństwo solidnych i ciężkich butów z czasów wojny ${ }^{74}$, choć ich prototyp, datowany na 1000 lat przed naszą erą, odnaleziono w grobowcu w Tebach. Uważa się, że były one symbolem statusu, bogactwa i pozycji osoby, do której należały ${ }^{75}$.

${ }^{69}$ L. Burcar, High heels as disciplinary practice of femininity in Sandra Cisneros's The House on Mango Street, Journal of Gender Studies, 2018, May, s. 1.

${ }_{70} \mathrm{C}$. Wobovnik, These shoes aren't made for walking: Rethinking high-heeled shoes as cultural artifcats, Visual Culture and Gender, 2013, s. 83, http://vcg.emitto.net/index.php/vcg/article/ view $/ 77 / 78$

${ }^{71}$ D. Kunzle, Fashion and Fetishism, s. 14.

72 C. Morton, How to Walk in High Heels? s. 17.

73 Tamże, s. 24.

${ }^{74}$ M.J. Bossan, The Art of the Shoe, New York 2004, s. 96.

75 N. Cawthorne, A Century of Shoes: Icons of Style in the 20th Century, Hardcover, 1997, November 1, s. 52. 
Przez kreatorów mody są postrzegane jako symbol „agresji, wyostrzonej seksualności i frywolnego nieposłuszeństwa niegrzecznej dziewczyny"76. Szpilki są jednak, poza kontekstem kulturowym, przedmiotem uwagi wielu specjalistów, począwszy od lekarzy, którzy obwiniają je za kontuzje kostek i bóle kręgosłupa, poprzez pracowników ochrony - zabrania się ich używania na ruchomych schodach, w samolotach i na śliskich powierzchniach, w końcu są wyzwaniem dla technologii - jak stworzyć obcas tak cienki i delikatny, a jednocześnie tak stabilny, aby utrzymać ciężar całego ciała kobiety ${ }^{77}$ Potencjalnie dwoistą interpretację butów na wysokich obcasach - w kontekście problemu władzy - prezentuje Sancactar, pisząc:

wysoki obcas to broń... ale także symbol falliczny. Jednocześnie czyni kobietę niepełnosprawną i pełną władzy. $Z$ jednej strony jest podporządkowana, nie może szybko się poruszać, traci równowagę, a stopy ją bolą - ale jest wyższa, ma na sobie ostro zakończoną rzecz, którą może wbić w ciało mężczyzny. W końcu mamy do czynienia ze sztyletem (stiletto) ${ }^{78}$.

Tak więc w drugim, przywoływanym już kilkakrotnie, nurcie myślenia zakłada się, aby nawiązać do poglądów Teal Swan, iż należący do trzeciej fali feminizmu feminizm typu stiletto zakłada, że uznawane przez główny nurt feminizmu jako opresywne wobec kobiet - wysokie obcasy, a także makijaż (szczególnie pomadka - stąd lipstic feminism) mogą być narzędziem upodmiotowienia i siły kobiet.

Możemy używać szminek i wysokich obcasów broniąc praw kobiet. Jestem pewna, że to bardziej efektywne niż palenie staników i protestowanie przed Kapitolem. Bardziej efektywne, ponieważ pozbawione stygmatu "okropnej feministki” czy ",antyseksualnej feministki"79. Nie ma bardziej autorytatywnego odczucia niż chodzenie po korytarzu w doskonałej parze szpilek - pisze Teal Swan - nic nie da się porównać do wyzwolenia, które odczuwam wybierając dowolny kolor i krój moich strojów, tak by pasowały do mojego nastroju. Nie czuję większego zadowolenia ponad zadowolenie z mojego odbicia w lustrze ${ }^{80}$.

Wysokie obcasy mogą być więc też, zdaniem niektórych teoretyków, narzędziem złamania patriarchalnej kontroli nad ciałem kobiet ${ }^{81}$. Chelo Aestrid

${ }^{76}$ L. O'Keeffe, Shoes: A Celebrations of Pumps, s. 123.

77 Rocket Scientist are Inventing a New High Heel? https:/ / www.youtube.com/watch?v=gNQDx59c7Uk

78 A. Sancactar, An Analysis of shoes within the context of social history of fashion, Izmir 2006, s. 62, http:/ / library.iyte.edu.tr/tezler/master/endustriurunleritasarimi/T000364.pdf

79 T.Swan, Stiletto feminism, 4.02.2014, https://tealswan.com/teals-blog/stiletto-feminism/

80 Tamże.

81 B. Pitt Do your high heels make a feminist or mysoginstic statement?, https:/ / bust.com/style/ 10710-do-your-high-heels-make-a-feminist-or-misogynistic-statement.html 
wskazuje, że w okresie oświecenia buty na wysokich obcasach służyły do uzyskiwania bardziej męskiego wyglądu (wysokiego wzrostu i autorytetu). Zdaniem tej samej autorki, współcześnie w środowisku profesjonalnym, czynią kobietę "bardziej dominującą i pełną władzy" ${ }^{82}$.

Podobnie uważa Lorraine Gamman, która powołując się na wypowiedź Simon Donnan zauważa, iż wysokie obcasy „kreują pewien poziom autorytetu" $^{\prime 33}$. A szpilki, pomimo znienawidzenia ich przez drugą falę feminizmu (Susan Brownimiller ${ }^{84}$, Germaine Greer ${ }^{85}$ ) kojarzą się młodym kobietom z seksualnym wyzwoleniem ${ }^{86}$. I trzeba tu wrócić do momentu, kiedy je wylansowano, lat 50., kiedy to były „w większej mierze symbolem wyzwolenia niż podporządkowania”, „progresywności niż regresywności”, „odrzuceniem konwencji" ${ }^{87}$.

Szpilki nie symbolizowały [i nadal nie symbolizują - uzup. AG-M] gospodyni domowej (...) kojarzone z glamour, z rebelią, z kimś kto jest nowoczesny (...), na czasie (...) kimś, kto jest w procesie przełamywania tradycyjnych ról kobiecych ${ }^{88}$.

Znakomicie ujmuje to Lee Wright, kiedy pisze powołując się na analizy Judith Williamson:

materialne rzeczy są wytwarzane po to, aby być reprezentacjami niematerialnych rzeczy, których potrzebujemy. Szpilki w swoich najbardziej ekstremalnych manifestacjach wychodziły daleko poza granice tego, co uznawano za akceptowalne - kluczowy czynnik posiadający zdolność za pomocą stylu przekazywania znaczeń buntu i dominacji (...) Obcas był tu kojarzony z bronią ${ }^{89}$.

Lynette Lewis w książce Climbing the ladder in stilettos: 10 strategies for stepping up to success stwierdza, iż „wspinanie się po drabinie (typowo męskie

82 Tamże.

83 L. Gamman, Self-Fashioning, Gender Display, and Sexy Girl Shoes: What's at Stake - Female Fetishism or Narcissism? [w:] Footnotes: On Shoes, red. S. Benstock, S. Ferris, London 2000, s. 98.

${ }^{84}$ S. Brownmiller postrzega szpilki jako tzw. buty gwałtu: "Jej ubranie blokuje jej swobodne ruchy (...) delikatne tkaniny (...) jedno szarpnięcie i bluzka jest rozdarta, jedno potknięcie i rajstopy są podarte (...) Jej delikatne buty mają paseczki, które z łatwością się przerywają i obcasy, które come loose. Ona nie może biec", S. Brownmiller, Against Our Will: Men, Women and Rape, New York 1993, s. 360. W innym miejscu nazywa je pomysłowym narzędziem „upośledzenia" kobiet, S. Brownmiller, Femininity, New York 1985, s. 186.

${ }^{85}$ Germaine Greer jest autorką kontrowersyjnego określenia, które zostało podchwycone przez międzynarodową prasę, „buty do seksu”. Uznała ona, iż wysokie obcasy nie nadają się do niczego więcej, "Jeśli kobieta nie zdejmie szpilek, to nigdy się nie dowie jak daleko mogłaby zajść i jak szybko biec", G. Greer, The Change: Women, Aging and Menopause, London 2018, s. 34.

${ }^{86}$ T. Edwards, Fashion in Focus: Concepts, Practices and Politics, London 2011, s. 82.

${ }^{87}$ L. Wright, Objectifying Gender: The Stiletto Heel, A View from the interior: feminism, women, and design, London 1989, s. 14-15.

88 Tamże.

89 Tamże, s. 17. 
zajęcie) w szpilkach (typowo kobieca ikona mody) brzmi niemal śmiesznie", jednak to właśnie szpilki towarzyszą kobiecie w wielu rolach społecznych. Wymienia ona czarne szpilki dopełniające wizerunek profesjonalistki, wraz z szarą spódnicą ołówkową i jedwabną zapinaną na guziki bluzką; szpilki z cienkimi paseczkami z ulubioną sukienką koktajlową w roli prywatnej; w końcu szpilki ze wzorem pantery do drogich designerskich dżinsów znakomicie podkreślające rolę rozrywkową ${ }^{90}$. I w kontekście, uznawanie butów na wysokich obcasach jako instrumentu męskiej dominacji nie wydaje się być uzasadnione.

Stiletto network (sieć szpilek) jest metaforyczną nazwą dla nowego pokolenia ambitnych kobiet osiągających sukcesy w zarezerwowanych dotąd dla mężczyzn gałęziach biznesu ${ }^{91}$. „Mają zdrowe włosy i szykowne buty. Czują się komfortowo w swojej skórze, nie próbują ubierać się, działać i brzmieć jak mężczyźni"92.

Nic więc dziwnego, że Hadley Freeman w artykule „Czy feministki mogą nosić wysokie obcasy?" pisze:

znam kobiety, które kochają obcasy. Niektóre z nich noszą je codziennie, a nie na specjalną okazję. Niektóre twierdzą, że bycie wyższą sprawia, że czują się silniejsze, bardziej upełnomocnione i czują się jak kaczki, kiedy noszą buty na płaskich obcasach.

\section{Choć przyznaje jednocześnie, że}

wysokie obcasy wprawiają mnie w zły humor; sprawiają, że nie jestem samodzielna, nie potrafię dojść do taksówki oddalonej więcej niż 50 yardów; sprawiają, że jestem nudna, ponieważ nie potrafię mówić o niczym więcej poza moimi zranionymi stopami ${ }^{93}$.

Bez wątpienia, warto tu zastanowić się nad znaczeniami wpisywanymi w buty na wysokim obcasie przez kobiety, które noszą je (lub nie) z własnego wyboru. Pytania, jakie można tu postawić odnoszą się do ich znaczenia/ symboliki w wizerunku kobiety profesjonalistki. Czy wysokie obcasy dodają jej powagi i autorytetu czy też seksualizują ją ${ }^{94}$ Czy kobieta-profesjonalistka pozbawiona wysokich obcasów traci swój urok i kobiecość?

Odwołując się do tezy Semmelhack, można stwierdzić, że wysokie obcasy przejęte od mężczyzn stały się - na przełomie wieków XIX i XX - emblematem maskulinizacji wizerunku kobiet, obok kapeluszy, krótkich włosów

${ }^{90}$ L. Lewis, Climbing the Ladder in Stilettos: 10 Strategies for Stepping Up to Success, Nashville 2006, s. 2.

91 P. Ryckman, Stiletto Network: inside the Women Power circles that are Changing the Face of Business, New York 2013, s. 1.

92 Tamże, s. 3.

93 H. Freeman, Can a Feminist Wear High Heels? "Guardian” 28.01.2013, https:/ /www.theguardian.com/fashion/2013/jan/28/can-feminist-wear-high-heels

94 M. Keane, B. Monte, Sex, Power, and High Heels. 
i palenia tytoniu ${ }^{95}$. Istnieje jednak i przeciwstawna teza, zgodnie $\mathrm{z}$ którą buty na wysokich obcasach miały „potwierdzać kobiecość sufrażystek w męskim świecie polityki"96. Na ten aspekt zwraca uwagę ta sama autorka, gdy pisze o poszukiwaniu przez nie pracy w zapinanym na guziki obuwiu $\mathrm{z}$ wysokim obcasem czy grze w tenisa w sportowych butach na wysokich obcasach, które miały zaprzeczyć tezie, zgodnie z którą uzyskanie praw wyborczych odbiera kobiecość ${ }^{97}$.

Można w tym miejscu przywołać poglądy H.M. Lips w kwestii symboliki ubioru kobiecego. Według niej, typowo kobiece stroje nie tylko zaprzeczają władzy, autorytetowi i kompetencjom, ale także - co jest raczej oczywiste podkreślają seksualność i emocjonalność osoby je noszącej. Stąd, kobietom pełniącym funkcje kierownicze zaleca się zrezygnowanie z długich rozpuszczonych włosów symbolizujących zmysłowość, a także z butów na zbyt wysokich i wąskich obcasach (utrudniają mobilność), minispódniczek i obcisłych bluzek. Preferowany styl to styl męski, zacierający różnice płciowe ${ }^{98}$. Typowe kobiety sukcesu

...ubierają się w zdecydowanie klasyczny sposób, nosząc głównie kostiumy albo żakiety, połączone z równie klasycznymi bluzkami. Kolorystykę ubrań ograniczają zazwyczaj do dwóch barw. Pokazują bardzo mało odkrytego ciała i noszą, również w lecie, rajstopy w kolorze skóry. Chodzą zawsze w pantoflach na średnim obcasie ${ }^{99}$.

Można tu niekiedy dostrzec jednak paradoks: oto kobiety te od czasu do czasu (np. idąc na eleganckie przyjęcie) „przyoblekają” tymczasowo tradycyjną kobiecość. Zakładają wówczas koronkową bieliznę, buty na wysokich obcasach, zwiewne sukienki i efektowną biżuterię. Stylizują się na obiekty seksualne, stylizują się na kobiecość esencjalną, zakładając maskę tradycyjnej kobiecości. Chociaż i w sferze wyglądu profesjonalistek dostrzec można pewne zmiany - niekiedy duże firmy zatrudniają konsultantów - po to, aby kobiety w niej pracujące "przestały wyglądać tak męsko" i zaczęły "urzeczywistniać swoją kobiecość"100. W tym kontekście wysokie obcasy wydają się znakomitym emblematem kobiecości profesjonalistek, które skracają włosy i rezygnują z koloru blond (mogącego wywoływać stereotypowe skojarzenia), chowają do szaf

\footnotetext{
${ }_{95}$ W. Kremer, Why did men stop wearing High Heels.

${ }^{96}$ G. Riello, P. McNeil, Footprints of History, s.36.

${ }^{97}$ E. Sammelhack, A Delicate Balance, [w:] Shoes. A History, s. 231.

${ }_{98}$ H.M. Lips, Women, men, and power, London 1991, podaję za: E. Mandal, Miłość, władza i manipulacja w bliskich związach, Warszawa 2008, s. 45.

99 C.E. Enkelmann, Strategia Wenus. Kobieta w świecie biznesu, Warszawa 2003, s. 119-120.

100 R. Steiner, N. McDermott, Wear high heels to embrace your femininity: Legal firm's advice to female lawyers, Mail Online. News, adres internetowy: http:/www.dailymail.co/news/article-1100551/Wear-high-heels-embrace-feminity-Legal-firms-advice-female-lawyers.html, 23.12.2008.
} 
koronkowe spódnice, zakładając paramęskie garnitury ${ }^{101}$. W niektórych przypadkach poddają się zabiegom wstrzykiwania botoksu bądź chirurgii estetycznej, korygującej kształt nosa czy podbródka, aby nadać swojej twarzy „businessowy wygląd". Jednocześnie dbałości o męski kształt wizerunku towarzyszą "dodatki", których celem jest zachowanie kobiecości (po to, aby osłabić wrażenie zmaskulinizowania). Są to bez wątpienia buty na wysokich obcasach (choć ich funkcja wyeksponowania wzrostu może wpisywać się do pewnego stopnia w logikę maskulinizacji), a także dodatki biżuteryjne ${ }^{102}$.

Grace Dent w artykule zatytułowanym „Nie rozdzielisz mnie od moich wysokich obcasów - jeśli to feminizm tysiąclecia, przyłączam się do patriarchatu”, nazywa kostium i szpilki profesjonalną „,zbroją":

kiedy masz do czynienia z setkami obcych, kurierami rowerowymi, zrzędliwymi ochroniarzami, pijakami, włóczęgami i zagubionymi turystami, to profesjonalny kostium damski jest jak zbroja. Ołówkowa spódnica, szminka, chmura perfum, trzy calowe obcasy.

Jest ona przekonana, że odpowiedni wygląd, którego nieodłącznym elementem jest makijaż i wysokie obcasy są wizytówką firmy, świadczą o powadze stanowiska, sprawiają, że kobieta staje się godna zaufania, inteligentna i wykształcona ${ }^{103}$. W badaniach M.A. Maarouf przeprowadzonych na grupie 200 egipskich kobiet, aż 68\% badanych menedżerek przyznało, iż preferuje wysokie obcasy, ponieważ są odpowiednie dla ich grupy zawodowej, sprawiają, że są one godne zaufania, a także podnoszą ich atrakcyjnośćn ${ }^{104}$.

Wysokie obcasy, choć obecnie dostępne dla wszystkich kobiet niezależnie od wielkości stopy i zamożności, są bez wątpienia kojarzone z pewnego rodzaju luksusem. (Nancy McDonell Smith uważa nawet, iż zastąpiły one, z uwagi na ich cenę, diamentowe bransoletki i prawdziwe futra ${ }^{105}$ ). Jego szczytem są - uważane za ikonę szpilek - buty projektanta Manolo Blahnika nazywane „butami do limuzyny” - ich wysokość sprawia, że trudno przemieszczać się w nich na większe odległości ${ }^{106}$. Warto wspomnieć tu ma-

101 S.A. Davies-Netzley, Women Above the Glass Ceiling. Perceptions on Corporate Mobility and Strategies for Success, Gender and Society, 1998, June, 12, 3, s. 349.

102 Szerzej na ten temat: A. Gromkowska, Kulturystyka, tożsamość i zdrowie w kulturze wspótczesnej, [w:] Ciało i zdrowie w społeczeństwie konsumpcji, red. Z. Melosik, Poznań - Torun 1999.

103 Independent (13 maja 2016), https://www.independent.co.uk/voices/you-wont-part-me-from-my-high-heels-if-this-is-millennial-feminism-im-joining-the-patriarchy-a7028676. html

104 M.A. Maarouf, The Impact of Wearing High Heels on Women's Health and Attractiveness: A Field Study, Journal of Basic and Applied Scientific Research, 2015, 5(8), s. 54.

105 N. McDonnell Smith, The Classic Ten: the True Story of the Little Black Dress and Nine Other, New York 2003.

106 S. Benstock, S. Ferriss, Introduction, [w:] Footnotes on Shoes, s. 5. 
jącą obsesję na punkcie drogich markowych szpilek Sarah Jessicę Parker, ikonę stylu naśladowaną przez miliony kobiet na całym świecie, główną bohaterkę kultowego serialu „Seks w wielkim mieście”. Stała się ona symbolem wyzwolonej kobiety, posiadającej pieniądze, które pozwalają jej żyć zgodnie z własnymi wyborami. Rozsławiła ona Manolo Blahnika nie tylko wydając na jego buty kilkadziesiąt tysięcy dolarów, ale traktując jedną z par jego szpilek jako zamiennik pierścionka zaręczynowego. W Europie, jak pisze O'Kneefee, obuwie zawsze odzwierciedlało podziały klasowe:

kobiety wiejskie i z klasy robotniczej zawsze nosiły wygodne buty (sensible), podczas gdy ich rozpieszczone koleżanki z klas wyższych były niewolnicami niepraktycznych, ale pięknych stylów, które odzwierciedlały uprzywilejowaną i leniwą egzystencję $e^{107}$.

Doskonałą egzemplifikacją postrzegania wysokich obcasów jako symbolu prestiżu, emancypacji i przynależności do klasy wyższej są kobiety będące podmiotem badań etnograficznych, ukazane w książce Carli Freeman High tech and high heels in the global economy. Women, work and pink-collar identities in the Carribean. Opisuje ona pracownice zatrudnione w prestiżowej - $\mathrm{w}$ ich kontekście kulturowym - profesji obsługi komputerów w centrum różnego typu danych (high-tech industry) na Barbadosie. Kobiety te noszą odważne kolorowe garsonki i lakierowane szpilki, które są dla nich emblematem profesjonalizmu:

wysokie obcasy są równie ważne dla tych kobiet, co dla przedsiębiorstwa, pisze C. Freeman, stanowią one znak, w połączeniu z procesorami danych, dzięki któremu ich szefowie, a także szersza społeczność odróżnia pracowniczki informatyczne od pracownic fabryki ${ }^{108}$.

Sprawia to, iż wysokie obcasy dla tych kobiet są oznaką prestiżu i wysokiej pozycji zawodowej. Autorka opisuje także przykład kobiet pracujących w fabryce przy linii produkcyjnej, które po zakończeniu pracy przebierają się w szpilki, aby na zewnątrz zakładu pracy uchodzić za kobiety należące do klasy średniej ${ }^{109}$.

Szpilki zawsze były kojarzone z seksualnością kobiety, czyniły ją bardziej atrakcyjną dla męskiego oka i bardziej kobiecą. Założenie ich po raz pierwszy przez dorastającą dziewczynę może być rozpatrywane w kontekście rytuału przejścia - symbolu dojrzałości seksualnej ${ }^{110}$.

${ }^{107}$ L. O'Keeffe, Shoes: A Celebrations of Pumps, s. 241.

${ }_{108}$ C. Freeman, High tech and high heels in the global economy. Women, work and Pink-Collar Identities in the Carribean, Duke 2000, s. 4.

109 Tamże.

${ }^{110}$ D. Kunzle, Fashion and Fetishizm, s. 13. Można też postrzegać ich symbolikę w kontekście rytuału przejścia do okresu starości - gdy zwykle kobiety rezygnują z ich noszenia, choć 
Warto odwołać się do rozważań Catherine Hakim, która uważa, że kobiety mają kapitał erotyczny (poza społecznym, kulturowym, czy ekonomicznym opisywanymi w teorii P. Bourdieu), który pozwala im na zdobycie bogatego partnera, ale także na lepszą pracę, czy mobilność społeczną w ogóle ${ }^{111}$. Autorka tej teorii wymienia sześć jego wymiarów, takich jak: piękno, atrakcyjność seksualna, umiejętności społeczne w zakresie nawiązywania relacji międzyludzkich i ich podtrzymywania (to, co sprawia, że ludzie cenią czyjeś towarzystwo), żywotność (połączenie poczucia humoru z pozytywną energią), styl (ubierania się, perfumy, biżuteria, makijaż, akcesoria) i seksualność samą w sobie ${ }^{112}$. Zgodnie z koncepcją kapitału erotycznego ma on największą wartość, kiedy „łączy się z najwyższymi poziomami kapitału ekonomicznego, kulturowego i społecznego", a przez to częściowo łączy się ze stratyfikacją społeczną. Kapitał ten, jak wskazuje autorka, podlega takim samym prawom, jak kapitał ludzki „wymaga podstawowego poziomu talentu i zdolności, przy czym może być kształcony, rozwijany i nabywany"113.

Morris, White, Morrison i Fisher przeprowadzili badania wskazujące na związek między noszeniem przez kobiety wysokich obcasów a ich atrakcyjnością seksualną. Uznali oni, iż wysokie obcasy mają wpływ na zmiany o charakterze biomechanicznym, to jest zmieniają sposób chodzenia "zmniejszając długość kroku i zwiększając obrót miednicy i bioder" ${ }^{\prime 14}$.

Z kolei, Nicolas Gue'guen przeprowadził eksperyment, w którym młoda kobieta ubrana w czarny biurowy kostium i białą bluzkę, nosząca czarne buty o rozmiarze obcasa: płaski, $5 \mathrm{~cm}$ i $9 \mathrm{~cm}$, prosiła mężczyzn o wzięcie udziału w badaniu dotyczącym równości płci. W drugim etapie cztery młode kobiety zapraszały mężczyzn i kobiety do uczestnictwa w badaniu na temat lokalnych zwyczajów żywieniowych. W trzecim etapie kobieta „nieświadomie” gubiła rękawiczkę, w czwartym czekała na poznanie mężczyzny w barze. Uczestnikami eksperymentu byli przypadkowo napotkani mężczyźni, a w drugim i trzecim przypadku także kobiety w wieku 25-50 lat. Okazało się, że w każdym z trzech przypadków mężczyźni chętniej godzili się i pomagali tym kobietom, których obcasy miały $9 \mathrm{~cm}$. W przypadku kobiet wysokość obcasa

w Internecie można odnaleźć dziesiątki adresów pokazujących starsze kobiety w szpilkach jako symbolu ich duchowej młodości i niezależności. Problem ten porusza m.in. J.J. Leganeur, All About Wearing High Heels, 2000.

111 C. Hakim, Erotic Capital, European Sociological Review, 2010, 26, 5.

112 Tamże, s. 500-501.

113 Tamże.

114 P.H. Morris i in., High Heels as supernormal stimuli: How wearing high heels affects judgments of female attractiveness, Evolution and Human Behaviour, 2012. 34, s. 176-181, podaję za: N. Gue'guen, High Heels Increase Women's Attractiveness, Arch Sexual Behaviour, 2014, Springer https://www.fitsnews.com/wp-content/uploads/2014/11/high-heels.pdf 
nie miała znaczenia ${ }^{115}$. Autor podaje możliwe wyjaśnienia tej zależności. Po pierwsze, wskazuje na zmianę percepcji długości stopy w butach na wysokim obcasie, która wydaje się mniejsza niż w rzeczywistości. Zwraca on w tym kontekście uwagę na preferencje mężczyzn w obszarze wielkości stopy kobiecej, stopa mała (jak w bajce o Kopciuszku czy kulturze chińskiej) jest bardziej atrakcyjna i kojarzona z młodością. Po drugie, im wyższy obcas, tym kobieta wydaje się smuklejsza i bardziej kobieca. W końcu, kobiety noszące wysokie obcasy wpisują się w wizerunki atrakcyjnych kobiet kreowane w przekazach medialnych ${ }^{116}$.

Na zakończenie stwierdzę, że w przeszłości binarna klasyfikacja na dominujących i podporządkowanych była bez wątpienia uzasadniona. Trajektorie władzy były jasno zdefiniowane i przebiegały wzdłuż podziałów klasowych, rasowych i płciowych. Zarówno dla teoretyków kultury, jak i uczestników życia społecznego - zwykłych ludzi - było oczywiste, kto ma władzę, a kto jej musi się podporządkować. W poszczególnych etapach historii arystokraci, burżuazja, biali, mężczyźni, czy przedstawiciele klas wyższych to byli ci, którzy poprzez swoje usytuowanie w hierarchii i strukturze społecznej dominowali, a chłopi, robotnicy, czarni, czy kobiety musieli wykonywać polecenia i realnie oraz symbolicznie podporządkowywać się. Wraz z upowszechnianiem $\mathrm{w}$ praktyce społecznej, przynajmniej w krajach Zachodu, ideałów równości, trajektorie władzy i podporządkowania przestały być oczywiste; władza uległa rozproszeniu, decentracji i fragmentaryzacji, na co słusznie zwracali uwagę poststrukturaliści. W jednym z moich tekstów przywołałam przykład czarnej prawniczki, do której po poradę udaje się biały biznesmen. Konfrontacje relacji władzy w jej różnorodnych uwarunkowaniach są $\mathrm{w}$ tym przykładzie oczywiste, nawet bardzo nisko usytuowane w hierarchii społecznej grupy trudno dziś uznać za ubezwłasnowolnione masy, potrafią oni nadawać własne znaczenie i tworzyć nisze oporu, niekiedy w wersji bardzo brutalnej. W ślad za tymi zmianami idą rekonstrukcje atrybutów przynależności do tych, którzy władzę mają. Tych, którzy jej podlegają, dotyczy to wszystkich aspektów życia społecznego, począwszy od luksusowych samochodów, ich podróbek, biżuterii i zasady podaruj sobie odrobinę luksusu, kiedy to kobieta z niskiej klasy kupuje sobie drogie perfumy, politycznych głosowań, w których to robotnicy w swojej milionowej rzeszy decydują, kto stoi u władzy. Można powiedzieć metaforycznie, że żadna forma arystokratyczności - że odwołam się do tego pojęcia - już dzisiaj nie istnieje.

W niniejszym tekście starałam się pokazać różnorodne uwikłania jednego tylko symbolu kobiecości - butów na wysokich obcasach. Ukazałam dys-

\footnotetext{
115 Tamże.

116 Tamże.
} 
kusję pomiędzy zwolennikami postrzegania ich jako formy męskiej opresji wobec kobiet a przedstawicielami nurtu emancypacyjnego, który postrzega w nich źródło władzy i upodmiotowienia kobiet. Po przeczytaniu tego tekstu uświadomiłam sobie, że z mojej perspektywy współcześnie ostrze tej dyskusji zasadniczo straciło na znaczeniu. Po pierwsze bowiem, nie można wyprowadzić żadnych obiektywnych kryteriów usytuowania wysokich obcasów w trajektorii władzy (kto śmiałby podważyć władzę pani prokurator w wysokich obcasach?) Analizy muszą więc wyraźnie pójść w stronę sytuacyjności i subiektywności ( $w$ tym pierwszym przypadku można podać przykład kobiety zmuszonej nosić wysokie obcasy w sekretariacie przez swojego pracodawcę, ale także kobiety, która poprzez swoje niebotyczne szpilki panuje wzrostem nad mężczyznami prowadząc spotkanie biznesowe). W drugim przypadku, w odniesieniu do subiektywności przywołać można banalne, ale istotne kategorie poczucia przyjemności i poczucia przymusu. Moim więc zdaniem, należy porzucić dyskusję na temat funkcji wysokich obcasów w systemie władzy i skoncentrować się na indywidualnych postrzeganiach przez kobiety roli, jaką wysokie obcasy odgrywają w ich życiu.

\section{BIBLIOGRAFIA}

Agaciński S., Polityka ptci, Warszawa 2000.

Art in Dress, The Art Amateur, 1882, 7, 4.

Barnish M., May Morgan H., Barnish J., The 2016 High Heels: Health effects and psychosexual benefits study: systematic review of reviews and additional primary studies, BMC Public Health, 2018, 18.

Bayles Kortsch Ch., Dress Culture in Late Victorian Women's Fiction. Literacy, Textiles, and Activism, Burlington 2009.

Benstock S., Fernill S., Footnotes on shoes, London 2001.

Bordo S., Unbearable Weight. Feminism, Western Culture and the Body, Berkeley - Los Angeles - London 1995.

Boris E., Feminist Currents, Frontiers: A Journal of Women Studies, 2010, 31, 1.

Bossan M.J., The Art of the Shoe, New York 2004.

Brownmiller S., Femininity, New York 1985.

Brownmiller S., Against Our Will: Men, Women and Rape, New York 1993.

Burcar L., High heels as disciplinary practice of femininity in Sandra Cisneros's The House on Mango Street, Journal of Gender Studies, 2018, May.

Cawthorne N., A Century of Shoes: Icons of Style in the 20 $0^{\text {th }}$ Century, Hardcover, 1997, November 1.

Chambers J., Cities without Maps, [w:] Mapping the Futures. Local Cultures, Global Change, red. J. Bird, London 1993.

Cline S., Spender D., Reflecting Men: At Twice Their Natural Size, London 1987.

Davidson H., Holding the Sole. Shoes, Emotion and Supernatural, [w:] Feeling Things: objects and emotions, Through History, red. S. Downes, S. Hollowey, S. Randles, Oxford 2018. 
Agnieszka Gromkowska-Melosik

Davies-Netzley S.A., Women Above the Glass Ceiling. Perceptions on Corporate Mobility and Strategies for Success, Gender and Society, 1998, June, 12, 3.

Duby G., Perrot M., A History of Women in the West, t. IV, Cambridge - Massachusetts London 1995.

Edwards T., Fashion in Focus: Concepts, Practices and Politics, London 2011.

Enkelmann C.E., Strategia Wenus. Kobieta w świecie biznesu, Warszawa 2003.

Fiske J., Understanding Popular Culture, London - New York 1991, s. 19-21.

Freeman C., High tech and high heels in the global economy. Women, work and Pink-Collar Identities in the Carribean, Duke 2000.

Freeman H., Can a Feminist Wear High Heels? "Guardian" 28.01.2013, https://www. theguardian.com/fashion/2013/jan/28/can-feminist-wear-high-heels

Freeman, H. Can't Do Heels? Don't Do Cannes, "Guardian", 2015, 20 May, https://www. theguardian.com/commentisfree/2015/may/20/heels-cannes-red-carpet-flat-shoes

Gamman L., Self-Fashioning, Gender Display, and Sexy Girl Shoes: What's at Stake - Female Fetishism or Narcissism? [w:] Footnotes: On Shoes, ed. S. Benstock, S. Ferris, London 2000.

Greer G., The Change: Women, Aging and Menopause, London 2018.

Gromkowska A., Kulturystyka, tożsamość i zdrowie w kulturze wspótczesnej, [w:] Ciało i zdrowie w społeczeństwie konsumpcji, red. Z. Melosik, Poznań - Torun 1999.

Gromkowska A., Kobiecość w kulturze globalnej. Rekonstrukcje i reprezentacje, Poznań 2002.

Gromkowska-Melosik A., Kobieta epoki wiktoriańskiej. Tożsamość, ciało, medykalizacja, Kraków 2013.

Gromkowska-Melosik A., Kopciuszek. Zagubiony szklany pantofelek i metamorfozy kobiecości, Studia Edukacyjne, 2017, 46.

Gue'guen N., High Heels Increase Women's Attractiveness, Arch Sexual Behaviour, 2014, Springer https:/ / www.fitsnews.com/wp-content/uploads/2014/11/high-heels.pdf

Hakim C., Erotic Capital, European Sociological Review, 2010, 26, 5.

Hinds H., Stacey J., Imaging Feminism, Imagine Femininity: The Bra-Burner, Diana and the Woman Who Kills, Feminist Media Studies, 2001, 1, 2.

Independent (13 maja 2016), https://www.independent.co.uk/voices/you-wont-part-me-from-my-high-heels-if-this-is-millennial-feminism-im-joining-the-patriarchy-a7028676.html

Jeffreys S., Beauty and Misogyny: harmful Cultural Practices in the West, London 2015.

Keane M., Monte B., Sex, Power, and High Heels: An Interview with Shoe Curator Elizabeth Semmelhack, Collectors Weekly, 2010, June, 18 th. https://www.collectorsweekly. $\mathrm{com} /$ articles/sex-power-and-high-heels-an-interview-with-shoe-curator-elizabethsemmelhack/

Khomami N., Receptionis "sent home from PwC for not wearing high heels", https:/ /www. theguardian.com/uk-news/2016/may/11/receptionist-sent-home-pwc-not-wearinghigh-heels-pwc-nicola-thorp

Kremer W., Why did men stop wearing High Heels, The BBC, 2013, January 25, https:/ / www. bbc.com/news/magazine-21151350

Kunzle D., Fashion and Fetishism. Corsets, tight-lacing and other forms of Body Sculpture, London 2006.

Ladies Home Journal, January 1908.

Lee Bartky S., Femininity and Domination: Studies in the Phenomenology of Opression, New York 1990.

Leganeur J.J., All About Wearing High Heels, 2000.

Lewis L., Climbing the Ladder in Stilettos: 10 Strategies for Stepping Up to Success, Nashville 2006. 
Linder M., Smart Women, Stupid Shoes, and Cynical Employers: e Unlawfulness and Adverse Healt Consequences of Sexually Discriminatory Workplace Footwear Requirements for Female Employees, Journal of Corporation Law, 1997, 2, 2.

Lips H.M., Women, men, and power, London 1991.

Maarouf M.A., The Impact of Wearing High Heels on Women's Health and Attractiveness: A Field Study, Journal of Basic and Applied Scientific Research, 2015, 5(8).

Maass V.S., The Cinderella Test: Would You Really Want the Shoe to Fit? Subtle Ways Women Are Seduced and Socialized into Servitide and Stereotypes, Oxford 2009.

Maguire E., Princessess and Pornstars: Sex, Power, Identity, Melobourne 2008.

Mandal E., Miłość, władza i manipulacja w bliskich zwiazkach, Warszawa 2008.

Matthews David A., Fashion Victims: The Dangers of Dress Past and Present, London 2015.

McDonnell Smith N., The Classic Ten: the True Story of the Little Black Dress and Nine Other, New York 2003.

Melosik Z., Tożsamość, ciało i władza w kulturze instant, Kraków 2010.

Morris P.H., White J., Morrison E.R., Fisher K., High Heels as supernormal stimuli: How wearing high heels affects judgments of female attractiveness, Evolution and Human Behaviour, 2012,34 .

Morton C., How to Wear High Heels. The Girls Guide to Everything, Paris 2006.

Muzzarelli M.G., Sumptoumous Shoes Making and wearing in Medieval Italy, [w:] Shoes. A History from sandals to sneakers, red. G. Riello, P.McNeil, Oxford - New York 2006.

O'Keeffe L., Shoes: A Celebrations of Pumps, Sandals, Slippers, and More, New York 1996.

Parmentier M-A., High heels, Consumption Markets \& Culture, 2016, 19, 6.

Payton M., Men's High Heels Race During Spanish Gay Pride is Simply Fabulous, 5. July 2015, https://metro.co.uk/2015/07/05/mens-high-heel-race-during-spanish-gay-pride-issimply-fabulous-5281244/

Pitt B., "Do your high heels make a feminist or mysoginstic statement?, https://bust.com/ style/10710-do-your-high-heels-make-a-feminist-or-misogynistic-statement.html

Rainbow flags and High heels, South Korea holds debut drag parade, 28.05.2018, http:/ / www.richmond-news.com/news/asia-pacific-news/rainbow-flags-and-high-heels-skorea-holds-debut-drag-parade-1.23315577

Rexford N.E., Women's Shoes in America, 1795-1930, Kent 2000.

Riello G., McNeil P., Footprints of History, History Today, 2000, 57, 3.

Rocket Scientist are Inventing a New High Heel? https://www.youtube.com/ watch? $=$ gNQDx59c7Uk

Ryckman P., Stiletto Network: inside the Women Power circles that are Changing the Face of Business, New York 2013.

Sancactar A., An Analysis of shoes within the context of social history of fashion, Izmir 2006, s. 62, http:/ /library.iyte.edu.tr/tezler/master/endustriurunleritasarimi/T000364.pdf

Semmelhack E., A Delicate Balance: Women, Power and High Heels, [w:] Shoes. A History from sandals to sneakers, red. G. Riello, P.McNeil, Oxford - New York 2006.

Steele V., Shoes and the Erotic Imagination, [w:] Shoes. A History from sandals to sneakers, red. G. Riello, P.McNeil, Oxford - New York 2006.

Steiner R., McDermott N., Wear high heels to embrace your femininity: Legal firm's advice to female lawyers, Mail Online. News, adres internetowy: http:/www.dailymail.co/news/ article-1100551/Wear-high-heels-embrace-feminity-Legal-firms-advice-female-lawyers.html, 23.12.2008.

Stuart A., Donaghue N., Choosing to conform: The discursive complexities of choice in relation to feminine beauty practices, Feminism and Psychology, 2011, 22(1).

Swallow A., The history of shoes, Baillieres Clinical Reumathology, August 1987, 1, 2. 
Swan T., Stiletto feminism, 4.02.2014, https://tealswan.com/teals-blog/stiletto-feminism/ Tanenbaum L., Bad Shoes and Women Who Love Them, New York 2010.

The Mystery of High Heeled Shoes: the Past and the Present, s. 4, https://www.shs.edu. tw/works/essay/2012/04/2012040309301379.pdf

The Reason Why This Japanese Bar Gives Discounts to Women Will Blow Your Mind, 16 June 2017, https:/ / www.alux.com/hilton-osaka-hotel-japan/

Toussaint-Sammat M., Historia stroju, przekł. K. Szeżyńska-Maćkowiak, Warszawa 1997.

Turner Wilcox R., The Mode in Footwear: A Historical Survey with 53 Plates, New York 2008.

Veblen T., The Thoery of the Leisure Class, London 2000.

Vertinsky P., Body Shapes: The Role of the Medical Establishment in Informing Female Exercise and Physical Education in Nineteenth-Century North America, London 1987.

Vianello A., Courtly Lady or Courtesman? The Venetian Chopine in the Ressaince, [w:] Shoes. A History from sandals to sneakers, red. G. Riello, P.McNeil, Oxford - New York 2006.

Wilson E., Adorned in Dreams. Fashion and Modernity, New York 2003.

Wobovnik C., These shoes aren't made for walking: Rethinking high-heeled shoes as cultural artifcats, Visual Culture and Gender, 2013, http://vcg.emitto.net/index.php/vcg/article/ view $/ 77 / 78$

Wright L., Objectifying Gender: The Stiletto Heel, A View from the interior: feminism, women, and design, London 1989. 